\title{
Impact and Control of Forest Diseases in Canada
}

\author{
by
}

\author{
R.D. Whitney ${ }^{1}$, R.S. Hunt ${ }^{2}$ and J.A. Munro ${ }^{3}$
}

\begin{abstract}
For the period 1977-1981, estimates of annual timber losses in Canada as a result of disease are 65 million $\mathrm{m}^{3}$. Intensive forest management presents an opportunity for utilizing pathological recommendations for reducing these losses in order to maintain forest productivity. Control of nursery diseases, root rot, dwarf mistletoes, and Dutch elm disease has been most successful. The accuracy of net inventory volume has been greatly improved. There is a need to develop more reliable surveys for loss estimates and to predict future losses, particularly on an individual stand basis. The utilization of biological information to develop new control strategies for use in intensive forest management is a challenge facing forest pathologists and forest managers in Canada today.
\end{abstract}

\section{Résumé}

Au Canada, les pertes annuelles de bois attribuables aux maladies ont été estimées à 65 millions de mètres cubes au cours de la période de 1977 à 1981. La gestion intensive des forêts offre l'occasion d'appliquer certaines recommandations pour réduire les pertes de cette nature afin de maintenir la productivité forestière. Les efforts de répression des maladies en pépinières, de lutte contre les pourridiés, les faux-guis et la maladie hollandaise de l'orme ont donné d'excellents résultats. L'exactitude des volumes nets d'inventaire a été grandement améliorée. II est nécessaire de metre au point des méthodes plus fiables pour l'estimation des pertes et la prévision des pertes futures, spécialement au niveau des peuplements pris individuellement. L'application des informations biologiques à l'élaboration de nouvelles stratégies de répression pour la gestion intensive des forêts représente un défi pour les pathologistes et gestionnaires forestiers du Canada d'aujourd'hui.

\section{Introduction}

Canada appears to be emerging from the exploitation era of forestry, when there was abundant old-growth timber, into a new period of tighter wood supplies. As a result, forest management will be intensified in much of Canada in the 1980s. In the last five years there has been a very noticeable increase in public and political awareness of the importance of forests and of their problems. In 1980, the forest industry contributed $\$ 22$ billion to the economy of Canada, thereby accounting for one dollar in every seven in the manufacturing sector (Anon. $1981 b)$. Forest products accounted for $\$ 12$ billion in our balance of trade, which was more than agriculture, mining and fishing combined.

To gain continued support for this scale of productivity and to meet the target set by the Canadian Council of Resource and Environment Ministers (Anon. 1981a), it is imperative that the forest resource be carefully and intensively managed.

1Great Lakes Forest Research Centre, P.O. Box 490, Sault Ste. Marie, Ont. P6A $5 \mathrm{M} 7$

2Pacific Forest Research Centre, 506 West Burnside Rd. Victoria, BC. V8Z1M5 ${ }^{3}$ Newfoundland Forest Research Centre, P.O. Box 6028, St. John's, Nfld. A1C $5 \times 8$

Department of the Environment, Canadian Forestry Service.
Because the forest land base is continually declining, forest managers will have to increase yields from the available land by all possible means. With rising values for forest products, there will be an improvement in the investment climate which will benefit forest management in general and pest management in particular. A major step would be taken toward increasing yields if losses caused by diseases were reduced considerably

The main objectives of this report are to describe the impact of tree diseases on Canada's forests, and to indicate the control measures available for combatting them. In 1982 the Canadian Forestry Service (CFS) conducted a review of its forest pathology research program with the aim of improving forest productivity in Canada. This paper is based on the final report resulting from that exercise.

\section{Impact of Tree Diseases}

Damage by tree diseases includes mortality, growth reduction, decay, deformation, and predisposition to windfall or to other pests. Several of these conditions can be present simultaneously, and they usually intensify over time. Other losses caused by tree diseases include delayed regeneration, stocking deficiencies, changes in stand composition, site degeneration, and reduced management options through the loss of 
disease-susceptible species such as white pine (Pinus monticola Dougl. and $P$. strobus L.). American elm (Ulmus americana L.) and American chestnut (Castanea dentata [Marsh.] Borkh.) (Davidson and Buchanan 1964, Baskerville 1980). Quantifying these damage factors as losses is often very difficult, and calculating economic loss is even more difficult. Also, the economic loss in productivity, e.g., when a stand has to be liquidated before reaching maturity and the resultant product has a lower value, should be taken into account.

However, except possibly in the case of Dutch elm disease and white pine blister rust, there has been little or no perceived effect of tree diseases on Canada's economy or standard of living. This is because much of Canada's timber harvesting has been in virgin stands. Dead or defective trees, lost increment and poor stocking attributable to diseases or other causes have accounted for little economic loss in these cases because there has been no investment in the stands. Only harvesting and transportation costs increase if more trees have to be harvested to offset volumes lost to diseases. As pointed out by Stiell (1976), "[t]he intensification of forest management is inevitably accompanied by a sharper awareness of forest enemies." Where money has been spent on plantations, the potential impact of any pest is important. Unfortunately, many forest managers are unaware of disease losses until they are catastrophic. It is therefore imperative that the effects of tree diseases on present and future volumes be accurately assessed and the information published. Anomalous situations must be clarified. For example, a conspicuous disease such as aspen shoot blight causes little loss, while an inconspicuous disease such as Armillaria root rot causes large losses.

"The most urgent need in forest pathology today is improved understanding of the magnitude of losses ... only in this way can appropriate guidelines be provided for our forest research and advisory services." (Horsfall and Cowling 1977) Although some improvements have occurred since this statement was made, our basic need is the same in 1983. Of 73 provincial and industrial forest managers replying to solicitations for information on tree diseases, 25 indicated a need for disease impact and damage statements. The following was typical of these replies: "Some basic form of an economic evaluation of losses caused by forest diseases (is required)

we would certainly like to know the economic effect of the disease prior to embarking on major control programs."

Annual losses from each disease are currently reported in cubic metres of wood, and no dollar values are placed on the pest or tree species involved. To place diseases in some sort of perspective, volumes lost are compared with volumes of wood harvested or burned in wildfires. Ultimately, the forester is interested in final stocking and product quality.

In 1964 Davidson and Buchanan published what was probably the first estimate of volumes lost to tree disease in Can- ada and the United States. A total of 27.1 million $\mathrm{m}^{3}$ was conservatively estimated to be lost annually in Canada. This did not take into account reduction in tree growth, delayed regeneration or deficiencies in stocking due to diseases. The next estimate, made in 1976, was increased to 40.4 million m $^{3}$ annually (Table 1) (Anon. 1979). This included some growth reduction as well as mortality and destruction of wood, but only on trees with measurable volumes (exclusive of elms killed by Dutch elm disease). About the same time it was estimated that annual timber losses to insects and diseases in British Columbia totalled more than 16 million $\mathrm{m}^{3}$, roughly $90 \%$ of which were due to diseases (Anon. 1978).

The largest contributors to the 1976 estimates, many of them in old growth stands, were trunk rots, root rots, dwarf mistletoes, and Hypoxylon canker (Table 1). The depletion does not include mortality in seedling or sapling stages caused by damping off, Scleroderris canker, root rot, or stem rusts, although losses to young and immature stands in the form of delayed regeneration, stocking deficiencies, growth reduction, and deformation are known to be considerable. Losses have not been quantified either for many foliage diseases or abiotic diseases such as frost damage, drought injury, sunscald, nutrient imbalance, and air pollution injury, although these diseases are known to cause mortality, deformation and/or growth reduction of Canadian trees.

At present it is difficult to obtain accurate estimates of tree volumes lost to all diseases because of inadequate mensurational and survey techniques and weaknesses in the national data base for forestry. Table 2 ranks, in a rough order of magnitude, the allowable cut, average harvest and annual forest losses due to pests for the period 1976-1981.

For many areas of Canada where forests are not managed intensively, summaries of area diseased, together with levels of mortality and growth impact of major disease agents, are sufficient. They are also useful for establishing long-term trends and research needs. However, for more intensively managed areas, detailed descriptions of present and projected losses on a management unit basis are required, often in a form that can be integrated with other data on soils, topography, vegetation and management constraints. Foresters would like to know what the effects of diseases on stocking, yield, stand composition and seed production in specific stands will be 10,20 or 50 years hence.

Survey techniques which provide estimates of the desired precision, use reasonable numbers of trained observers and include predictions of future losses are very much needed. Fragmentary and imprecise data on disease losses are currently being used simply because nothing better is available. Some of the best information on damage, survey, and volume losses is for root rots (Bloomberg 1981) and stem rots in certain regions. For example, root rot losses are determined for sapling- or pole-sized trees from plots or line surveys in

Table 1. Forest disease loss estimates in Canada for 1976 (from Anon. 1979, p. 14).

\begin{tabular}{|c|c|c|c|c|}
\hline \multirow{2}{*}{$\begin{array}{l}\text { Disease or } \\
\text { disease grouping }\end{array}$} & \multirow[b]{2}{*}{ Mortality } & $\begin{array}{l}\text { Growth } \\
\text { reduction }\end{array}$ & $\begin{array}{c}\text { Wood } \\
\text { destruction }\end{array}$ & \multirow[b]{2}{*}{ Total } \\
\hline & & \multicolumn{2}{|c|}{ (million $\mathrm{m}^{3}$ per year) } & \\
\hline Stem rots & - & - & 24.8 & 24.8 \\
\hline Root rots & 1.7 & 3.4 & - & 5.1 \\
\hline Dwart mistletoes & - & 4.7 & - & 4.7 \\
\hline Hypoxylon canker & 3.8 & - & - & 3.8 \\
\hline White pine blister rust & 0.6 & - & - & 0.6 \\
\hline \multirow[t]{2}{*}{ Miscellaneous diseases ${ }^{a}$} & 0.3 & 1.1 & - & 1.4 \\
\hline & & & & $\overline{40.4}$ \\
\hline
\end{tabular}

\footnotetext{
a includes other rusts, pole blight. Atropellis canker and the disease aspect of insect-disease complexes such as blue stain-bark beetle complex, maple decline and ash dieback.
} 
Table 2. Comparison of estimates of annual wood supply with annual cut and losses to diseases and insects (hardwoods and softwoods).

\begin{tabular}{lc}
\hline Item & Volume (millions of $\mathbf{m}^{3}$ per year) \\
\hline Canada's allowable annual harvest & $276^{\mathrm{a}}$ \\
Economically accessible volume & $212^{\mathrm{b}}$ \\
Annual cut (1980) & $156^{\mathrm{c}}$ \\
Annual losses to diseases (1977-1981 average) & $65^{\mathrm{d}}$ \\
Annual losses to insects (1977-1981 average) & 63 \\
\hline
\end{tabular}

a Selected Forest Industry Statistics for Canada compiled by J. Nicolaitt, CFS Headquarters. 1982

${ }^{b}$ Calculated from Tables 25 and 26. Vol. 1 (Reed 1978). Total of average harvest plus accessible volume from physical timber reserve.

CStatistics Canada.

dFrom Sterner and Davidson 1982. The figure for diseases includes losses from mortality and growth reduction due to rots (197 million $\mathrm{m}^{3}$ ), which were excluded from that paper because of incomplete survey records from all of Canada.

which the proportion of infected trees is determined on an area basis. Estimates obtained for the incidence of Phellinus root rot can be simulated to predict future volume reduction. It is almost as essential for forest managers to be able to predict disease losses accurately as it is for them to be able to control them (Hepting 1970). Therefore, it is important to establish communications between forest managers and those developing measuring techniques, conducting surveys, and undertaking economic evaluations.

As is shown in Table 2, about $57 \%$ of the annual allowable harvest is currently being harvested. However, indications are that the supply picture is considerably tighter than these figures indicate, because the biologically allowable annual harvest estimate includes considerable areas and volumes that are not economically accessible. The portion of the allowable annual harvest that is economically accessible has not been precisely defined, but data compiled by Reed (1978) indicate that it was in the order of 212 million $\mathrm{m}^{3}$ for the mid-1970s. (This is the sum of the average harvest plus the annual amount available from an estimated physical timber reserve.) However, national averages can be deceptive, glossing over regional supply shortages. The recent federal forestry sector strategy paper approved by Cabinet (Anon. 1981 b) states that:

"A more systematic analysis by region quickly reveals

that softwood shortages are pervasive, especially for

sawlogs and veneer logs. Any softwood reserve that

does exist on paper is generally characterized by

remoteness, high logging costs, or less attractive

grades and species.

The evidence presented here shows that only four provinces have uncommitted softwood timber reserves and

that these reserves are largely uneconomic

One way to alleviate tight regional wood supply problems is to reduce current losses to diseases, insects and fire. Reduction in disease loss of about $30 \%$ would make available an additional 20 million $\mathrm{m}^{3}$ a year for future expansion of the forest industry. This is about $10 \%$ of the Canadian Council of Resource and Environment Ministers' goal for increased wood production by the year 2000 (Anon. 1981a). Much of this increase should be in areas in which wood supply shortages are now being experienced or are expected in the near future. In terms of 1980 forest industry statistics, an additional 20 million $\mathrm{m}^{3}$ of timber harvested and utilized by the forest industry could be expected to provide about 39,000 person-years of employment and $\$ 800$ million in wages, and to increase the total value of forestry shipments by $\$ 2.9$ billion.

\section{Present Status of Forest Disease Control}

Forest disease control in Canada has taken many forms. By acquiring knowledge of the pest organism, host and environment, the forest pathologist has made recommendations that will prevent the eruption of disease epidemics, and will minimize damage by diseases. These recommendations involve reducing logging injuries, avoiding silvicultural practices that increase disease susceptibility, eliminating cull or diseased trees or susceptible portions of trees, altering species composition, maintaining genetic diversity by using species that are adapted to local climates and pathogens, or using species that have been selected for disease resistance. Control of stem rot in living trees is being accomplished mainly by reducing rotation ages (Waters and Cowling 1976).

Many of the control techniques for pathological problems must be worked in with management and silvicultural practices. Until recently, levels of forest management in Canada were such that many of these silvicultural practices were not in use. This situation, however, is changing. For example, a Forest Pest Management Section, with a staff of 52, has been established in the British Columbia Ministry of Forests (BCMF).

Research results have been incorporated into Canadian forest management plans where appropriate (Table 3). Some examples of disease control recommendations follow.

\section{a) Stem Rots - Inventory Refinement}

Studies in the early 1950 s revealed that the incidence of stem rot was extremely variable among and within host species, and it was related to many factors, such as tree age, growth rate, stand history and site. Research results were incorporated into provincial forest inventories for all commercial tree species in Canada, and this resulted in more precise estimates of wood volumes. These estimates in turn have been used in adjusting scaling regulations, setting stumpage

\begin{tabular}{|c|c|}
\hline Disease & $\begin{array}{l}\text { Control or benefit derived } \\
\text { from research }\end{array}$ \\
\hline Annosus root rot & Chemical stump treatment. \\
\hline $\begin{array}{l}\text { Phellinus, Armillaria and } \\
\text { Polyporus root rot }\end{array}$ & $\begin{array}{l}\text { Priority cutting, inoculum reduction, } \\
\text { site selection. }\end{array}$ \\
\hline Stem rot & $\begin{array}{l}\text { More precise stand volume } \\
\text { estimates. Reduced rotations to } \\
\text { avoid excessive losses from stem } \\
\text { rots. }\end{array}$ \\
\hline Stem deterioration & $\begin{array}{l}\text { Salvage losses at various periods } \\
\text { following tree death. }\end{array}$ \\
\hline Dwart mistletoe & Sanitation, prescribed fire. \\
\hline Scleroderris canker & $\begin{array}{l}\text { Sanitation, nursery fungicides, } \\
\text { species selection. }\end{array}$ \\
\hline Nursery diseases & Fungicides. \\
\hline $\begin{array}{l}\text { White pine } \\
\text { blister rust }\end{array}$ & $\begin{array}{l}\text { Hazard zoning, sanitation near } \\
\text { nurseries and seed orchards, } \\
\text { pruning. }\end{array}$ \\
\hline Dutch elm disease & $\begin{array}{l}\text { Sanitation, chemical injection, bark } \\
\text { beetle control. }\end{array}$ \\
\hline
\end{tabular}


rates, planning allowable cuts on specific areas, and calculating net merchantable volumes for permit cuts.

\section{b) Root Rot Control}

As a result of two decades of research followed by a series of workshops convened by forest pathologists in British Columbia, forest managers can reduce root diseases by priority cutting, inoculum (infected stumps and roots) removal, reduction of inoculum size by root raking, and use of more resistant species (Morrison 1981).

Forest pathologists in Newfoundland have recommended seeding rather than planting on certain sites in reforestation because planted trees were found to be more frequently attacked and killed by Armillaria mellea (Vahl ex Fr.) Kummer. Chemical treatments have been developed to prevent stump infection by Fomes annosus (Fr.) Karst. and these treatments are routinely used in commercial thinning operations in southern Ontario and in coastal British Columbia.

\section{c) Disease-Site Relationship}

In Ontario, fast-growing black spruce (Picea mariana [Mill.] B.S.P.) trees appear to be more susceptible to stem rot than their slower-growing neighbors (Basham 1973). Hence, practices currently in use to accelerate the growth rate of this species, such as fertilization or site improvement by drainage may well raise productivity but may also increase the incidence of butt and stem decay. Conversely, jack pine (Pinus banksiana Lamb.) grows significantly faster on moderately moist sites throughout Ontario while stem decay is significantly higher on the poorer, dry or very dry sites. Although jack pine is more difficult to establish and maintain on moist sites. largely because of competition, the advantages of such establishment suggest that it deserves consideration, especially where difficulties are experienced in regenerating spruce. Polyporus root rot of spruce is more prevalent on dry, thin, light-textured soils, and spruce grown on such sites will probably be attacked by this root disease prior to maturity. Sites favoring understory western hemlock (Tsuga heterophylla [Raf.] Sarg.) more than 40 years old will contain latent infections of Echinodontium tinctorium (Ell. and Ev.) Ell. and Ev. and should be destroyed during site preparation.

Trembling aspen (Populus tremuloides Michx.) is a relatively defective species, but decay research in Ontario has shown that, if stands are cut before they reach 80 years, losses can be held to an acceptable limit. Studies in both Ontario and Manitoba have revealed striking differences among aspen clones in growth rate and susceptibility to decay; however, in most cases in Ontario the fastest-growing clones are also the most defective. Studies of poplar in Alberta suggest that there is more decay on mesic than on dry sites.

\section{d) Deterioration of Killed Timber}

Usually several different fungi, each causing a characteristic decay, are responsible for deterioration after trees die. The rate at which they penetrate and destroy the outer stem wood depends on several factors. These matters have been studied and elucidated in the case of white pine, red pine (Pinus resinosa Ait.) and jack pine killed by fire; balsam fir (Abies balsamea [L.] Mill.) killed by the spruce budworm; and western hemlock killed by the hemlock looper. Managers now have access to information concerning salvage periods after tree death and the extent of stem deterioration at varying intervals following mortality.

\section{e) Decay and Stain of Maple}

Mature sugar maple (Acer saccharum Marsh.) trees frequently contain considerable stem stain and decay asso- ciated with dead branches. Young sugar maple were found to possess the ability to self-prune dead branches rapidly, mainly by the formation of localized decay pockets at the branch bases. In vigorously growing trees, small diameter branch stubs (less than $38 \mathrm{~mm}$ ) are rapidly healed over, killing or rendering harmless any decay-causing fungi present and preventing the spread of decay into the stem. Thus, in sugar maple there is a natural mechanism to minimize decay development and at the same time produce sound stems of good form. This process can be assisted by establishing dense stands and following this with crop tree release to promote good growth rate and rapid stub healing.

\section{f) Wound Prevention}

Studies in white spruce (Picea glauca [Moench] Voss), alpine fir (Abies lasiocarpa [Hook.] Nutt.), white pine, sugar maple and yellow birch (Betula alleghaniensis Britt.) have shown that trunk wounds, especially those larger than about $20 \mathrm{~cm}^{2}$ and deep into the wood, should be avoided as a precaution against decay. Certain wound types such as felling scars, logging machinery wounds, broken tops, sunscald wounds and fire scars are most likely to result in decay. These wounds result mainly from human activity and can be largely avoided by modifying logging methods. Once a stem wound is healed over, there is very little expansion of the decayed zone. Hence, wounds in small trees are far less serious than those in larger trees provided that they are not too wide and the trees are of relatively high vigor.

\section{g) Control of Mistletoes}

Because of their slow rates of spread, relatively narrow host ranges and ease of detection, dwarf mistletoes are very amenable to control. Measures consist of cutting or burning individually affected trees or clearcutting entire forest stands. Dwarf mistletoes cause such serious losses of growth in many major coniferous species that their control provides a practical means of greatly increasing yields.

The importance of dwarf mistletoe and the effectiveness of past surveys, research and technology transfer (e.g., publications and workshops) are manifested in the relatively high level of control activity, and in the guidelines for prevention and control that have been issued by the BCMF. The BCMF (Anon. 1980) estimates that losses from mistletoe could be reduced by $50 \%$ to $80 \%$ over the next crop rotation. Guidelines and procedures for dwarf mistletoe control are specified in various forms, e.g., cutting permits, contracts, silvicultural manuals, annual reports and technical reports (ibid.). In 1980 some 2300 ha were subjected to silvicultural control measures by the BCMF and by private industry.

\section{h) Control of Cankers}

The results of research into the control of Scleroderris canker of pines are being applied by the Ontario Ministry of Natural Resources, by the Quebec Ministry of Energy and Resources in nurseries and plantations, and in some nurseries in the Maritimes. Species less susceptible than red pine are recommended for use in areas of northern Ontario. Potential infection sources can be reduced by eliminating host tree species, or cutting out infected individuals or branches in the vicinity of nursery beds. Culling can be accomplished by a careful inspection of the beds immediately before lifting with removal and destruction of infected seedlings. Finally, fungicides (chlorothalonil, maneb, ziram) can be applied after each rain and possibly following overhead irrigation if Scleroderris is present or suspected in the nursery. An accurate and early estimate of disease incidence and distribution in a new plantation gives the forest manager an excellent position from which 
to judge whether control measures should be applied and what they should be (Dorwroth 1976). Attempts have been made to eradicate the much more dangerous European race of the fungus from Newfoundland and New Brunswick following recommendations of forest pathologists.

Recommendations for control of Atropellis canker of lodgepole pine (Pinus contorta Dougl. var. latifolia Engelm.) in Alberta include prescribed burning, clearcutting, thinning and removal of residuals (either seed trees or noncommercial residuals) by a given age of the regeneration.

\section{i) Control of Seedling Diseases}

One of the most successful areas of application of forest pathology research is in nurseries. Hundreds of millions of seedlings are grown annually in Canada with comparative freedom from diseases as a result of the timely application of seed coatings, fungicides, crop rotations and soil fumigation procedures recommended largely by pathologists (Wall 1978 , Sutherland and Van Eerden 1980). These measures protect seedlings from attack by many diseases.

Pathologists have established procedures for handling spruce seed that have assisted an export business. In British Columbia many more western hemlock seedlings would have to be grown to meet reforestation requirements if Botrytis gray mold were not controlled.

\section{j) Control of Rusts}

Eastern white pine is again being recommended for planting in some sections of Quebec as a result of the establishment of hazard zones for white pine blister rust. Removal of lower branches (pruning) is recommended as a means of reducing losses to this rust in British Columbia. Resistant trees will likely be used in the future.

To control cone rusts of spruce and stem rusts of pine, both pine and the alternate host are eliminated from within and around seed orchards. Needle rust of Douglas-fir (Pseudotsuga menziesii Mirb. Franco) and stem rusts of lodgepole pine are controlled by similar sanitation practices around nurseries.

\section{k) Control of Dutch Elm Disease}

High-value elms can now be saved from Dutch elm disease with root-flare injections of benomyl and sanitation procedures. These recommendations by pathologists have saved thousands of elms in Canadian cities (Kondo 1982).

Antibiotics obtained from microorganisms were developed in the Maritimes Forest Research Centre for testing against the causal fungus of Dutch elm disease, stain and mold fungi of wood, and wood destroying fungi (Stillwell et al. 1973). Promising results were obtained with cryptosporiopsin, hyalodendrin, and scytalidin for control of disease-causing fungi and stains in wood chip piles. As spinoff from the research, these antibiotics were tested in many fields for possible use in medicine and agriculture.

\section{I) Control of Exotic Diseases}

Information on the presence and distribution of pests has been supplied by Canadian forest pathologists to members of the Plant Products and Quarantine Division of Agriculture Canada as an aid to the Division in fulfilling its function of keeping unwanted pests out of Canada.

\section{Discussion and Conclusions}

Prevention rather than correction of tree diseases should be the policy of future forest management. Understanding the ecosystem is essential if trees are to be grown under conditions in which prevention can be practised. Prevention of diseases and minimization of losses depends largely on the ability of forest managers to anticipate disease problems before they develop, and to devise planting and management plans that will result in relatively disease-free forests. The principles of prevention include inoculum reduction, minimization of predisposition and minimization of environmental conditions favorable to disease development.

There are many examples of silvicultural practices that have resulted in serious losses to disease years after stand establishment because pathological hazards were not recognized. If the lush seedlings a forester receives have hockeystick roots from nursery transplanting, or the roots are dry or moldy from improper storage, they should be destroyed. If the area being planted is sandy and rapidly drained, a species such as jack pine which will survive and grow there should be selected. If the desired species is not available, the planting must be postponed. Forest pathologists must make disease prevention information available to the managers, and develop survey techniques for their use.

The use of scarification is increasing as a method of preparing cutover areas for conifer regeneration. However, where the fast-growing young poplar suckers are damaged but not killed, this species may still develop into the main crop species on the site, while the resulting wounds will serve as major infection courts for pathogens. Scarification practices should be reviewed.

An added benefit of thinnings or tree improvement cuts is that they provide an opportunity for removing diseased or disease-prone trees, and inoculum sources such as infected stumps, roots, branches, etc. At the same time, however, stand improvement machinery inevitably results in wounds to residuals which can be ideal entrance courts for disease fungi. Treatments or refinements to logging equipment or procedures, such as logging on snow to prevent wounding to residual crop trees, should be developed.

Trees in urban areas consistently have problems of a very special nature because of their high individual values, because of site disturbance factors, and because they are often exotics. Pollution and other urban conditions pose very difficult problems for pathologists. Introduced diseases are often first encountered in urban areas (Dutch elm disease and chestnut blight); therefore, these trees deserve particular attention.

Biological control, or the manipulation by man of any living organism for pest control purposes, holds great promise in the control of plant diseases. Many successful instances of disease control through the use of biological agents have been reported, but nearly all of them remain at the experimental stage. One of the two commercially available biological control agents for plant diseases in the United States is for a tree disease Annosus root rot (Schroth and Hancock 1981). Other biological controls for tree diseases such as mycorrhizal fungi or the use of Trichoderma spp. and Ascocoryne sarcoides (Jacq. ex Gray) Groves and Wilson against Armillaria root rot and decay in living trees have been suggested in the literature. Biological control has worked in some instances, but often a tremendous amount of information is needed for its successful application.

Further clarification of host-parasite relationships is also needed for young stands, as aspects of this interaction will be used in simulation models of future disease losses.

We hope that a new era is dawning in which diseases will be studied in concert with insect attack and adverse environmental factors. Too often in the past only one of the above aspects of a problem has been addressed, although there have been some notable exceptions. Trees can be expected to have combinations of problems acting together in a disease syndrome. In Volume 5 of their treatise, Horsfall and Cowling (1980) state: "[R]arely is disease caused by a single agent; 
cause is complex, and its study is just as complex...." Research on diseases would be more successful if expertise from several disciplines were brought to bear on the problem.

In the future, consideration of diseases must form an integral part of forest planning for seed production, rearing of seedlings, selection of planting sites, tending of stands, and harvest and utilization of mature forests. Environmental diseases, including industrial pollution and acid rain, will have increasing impacts on forest stands as well as on urban amenity forests. Changes in stand history, composition and environment will encourage some diseases and discourage others in ways that are not yet fully understood. Diseases that were of little importance in old forests may become serious threats to younger stands grown under different conditions.

The impact of tree diseases can be stated in general terms and considerable progress has been made in understanding and controlling diseases. However, much remains to be done, both by the pathologist and by the forest manager, to reduce losses to acceptable levels.

\section{Acknowledgments}

The authors wish to acknowledge all forest pathologists, forest researchers, forest research administrators, forestry professors and provincial and industrial forest managers throughout Canada who contributed to the recent Review of Forest Pathology in the Canadian Forestry Service on which this paper is based.

\section{References}

Anon. 1978. Report for year ended Dec. 31, 1978. BC Min. For. 26 p.

Anon. 1979. Our forest resources. Dep. Environ., Can. For. Serv., Ottawa, Ont. Inf. Rep. DPC-X-9, 14 p.

Anon. 1980. Forest and range resource analysis technical report. BC Min. For.

Anon. 1981a. Critical choices in the management of the forestry sector. Dep. Environ., Can. For. Serv., Ottawa, Ont. 247 p.

Anon. 1981b. A forest sector strategy for Canada. Discussion paper. Dep. Environ., Can. For. Serv., Ottawa, Ont. 26 p. + appendices. Basham, J.T. 1973. Heart rot of btack spruce in Ontario. I. Stem rot, hidden rot and management considerations. Can. J. For. Res. 3(1): 95-104.

Baskerville, G.L. 1980. Insects, diseases and forest management. p. 52-54 in The forest imperative: proceedings of Canadian Forest Congress. Sept. 22-23, 1980.
Bloomberg, W.J. 1981. Estimation and prediction of losses caused by Phellinus weirii root rot in second-growth stands in coastal British Columbia. Victoria, BC, Sept. 1981.

Davidson, A.G. and Buchanan, T.S. 1964. Disease impact on forest production in North America. FAO/IUFRO Symp. on internationally dangerous forest diseases and insects. Oxford, England.

Dorworth, C.E. 1976. Reducing damage to red pine by Gremmeniella abietina in the Great Lakes-St. Lawrence forest of Ontario. Dep. Environ., Can. For. Serv., Sault Ste. Marie, Ont. Inf. Rep. O-X-252, $22 p$.

Hepting, G.H. 1970. The case for forest pathology. J. For 68: 78-81.

Horsfall, J.G. and Cowling, E.G. 1977. Plant disease an advanced treatise. Vol. I. How disease is managed. Academic Press, New York, $465 p$.

Horsfall, J.G. and Cowling, E.B. 1980. Plant disease an advanced treatise. Vol. V. How plants defend themselves. Academic Press, Toronto, $534 \mathrm{p}$.

Kondo, E.S. 1982. Integrated systems of control of Dutch elm disease in Canada. p. 129-136 in E.S. Kondo, Y. Hiratsuka and W.B.G. Denyer, Ed. Proc. Dutch Elm Disease Symposium and Workshop, Winnipeg, Man.

Morrison, D.J. 1981. Armillaria root disease, a guide to disease diagnosis, development and management in British Columbia. Dep. Environ., Can. For. Serv., Victoria, BC. Inf. Rep. BC-X-203, $15 p$.

Pomerleau, R. 1979. Forest pathology in Quebec from the early days to the present. (original in French) Phytoprotection 60 (Suppl.): 3-9.

Reed, F.L.C. 1978. Forest management in Canada. Dep. Environ., Can. For. Serv., Ottawa, Ont. Inf. Rep. FMR-X-102. 155 p.

Schroth, M.N. and Hancock, J.G. 1981. Selected topics in biological control. Annu. Rev. Microbiol. 35: 453-476.

Sterner, T.E. and Davidson, A.G. 1982. Forest insect and disease conditions in Canada, 1981. Dep. Environ., Can. For. Serv., Ottawa, Ont. $46 \mathrm{p}$.

Stiell, W.M. 1976. White spruce artificial regeneration in Canada. Dep. Environ., Can. For. Serv., Ottawa, Ont. Inf. Rep. FMR-X-85, $275 p$.

Stillwell, M.A., Wall, R.E. and Strunz, G.M. 1973. Production, isolation, and antifungal activity of scytalidium, a metabolite of Scytalidium species. Can. J. Microbiol. 19: 597-602.

Sutherland, J.R. and Van Eerden, E. 1980. Diseases and insect pests in British Columbia forest nurseries. BC Min. For./Can. For. Serv., Joint Publ. No. 12, 55 p.

Wall, R.E. 1978. Disease control in forest nurseries. Dep. Environ., Can. For. Serv., Fredericton, NB. Inf. Rep. M-X-84, 38 p

Waters, W.E. and Cowling, E.B. 1976. Integrated forest pest management. A silvicultural necessity. p. 149-177 in J.L. Apple and R.F. Smith, Ed. Integrated pest management. Plenum Press. 